\title{
The Emergence and Institutionalisation of Technology Assessment in Finland
}

\author{
Reijo Miettinen, Riikka Eela and Mikko Rask
}

The term technology assessment (TA) refers to activities or methods with which the impact of technology on society are identified and analysed. The results of the assessment are transmitted to the political decision-making process. The institutional starting point for TA activity was the establishment of the Office of Technology Assessment (OTA), in the Congress of the United States, in 1972. In the 1980s, smaller parliamentary technology assessment units were founded in fiveEuropean countries and in the European Parliament. In the wake, several European parliaments have expressed their interest in initiating assessment activities, among them the parliaments of Finland, Italy and Greece(Vig, 1997). In thispaper, weshall analyse the history of the institutionalisation of the parliamentary technology assessment in Finland and compare it with theTA practices in other European countries.

In theanalyses of theinstitutionalisation of European parliamentary technol- ogy assessment units, two basic models havebeen designated. Thetraditional or instrumental model, inherited from the OTA, is based on the idea of supplying strict, objective scientific and expert knowledge to the Members of Parliaments in order to help them make informed decisions concerning technology. This model was adopted in France, England and in Germany. In these countries, the TA unit is located within the Parliament. The newer model is the model of participatory or "discoursive" technology assessment. It takes democracy and public participation as focal starting points for organising theassessment. This model has been accepted in Denmark and theNetherlands wherethe TA agencies were set up as independent bodies with only a loose connection to the parliament.

One of the best known forms of the participatory TA is the consensus conference developed in Denmark by the Danish Board of Technology. Set up as a three-day conference, this method com- 
bines the knowledge of experts and the common sense of laymen (Agersnap, 1992; Cronberg, 1992). The experts present their views and opinions during the first day. The panel of laymen selected for the conference pose questions to them on the second day. The third day, the panel of laymen formulate and present a concluding report which summarises their agreement or disagreement on the questions of the state of art, risks, future use and need of controlling the technology. The consensus report is disseminated not only to theParliament, but also to different stake-holders in the society. The conference and its results are widely reported in the media. The consensus conference as method of technology assessment has been introduced in mostWest European countries, the USA and Japan during the 1990s (Ayano, 1999).

In the countries where traditional, instrumental model of technology assessment is dominant, the initiative for TA activities has usually been taken by the parliament (Vig, 1997). In the Netherlands and Denmark again, the original initiative was made by academies, socially responsible scientists, unions, other non-governmental organisations and government ministries. The model and the methods ofTA seem to be related to thesocial and institutional basis of the initiative. The differences of national political cultures have been analysed to explain the different ways of organising the parliamentary technology assessment.

In Finland, the institutionalisation of technology assessment has followed largely the traditional model. We shall analyse the phases of this institutionalisation, theactors that participated in the process and the particularities of the Finnish solution thus far. We shall also indicate some historical and political factors that have been influential in the formation of the Finnish parliamentary technology assessment solution. Lastly, we shall discuss some future problems and challenges.

\section{Early Initiatives: The Sitra Proposal of 1976}

Discussion on technology assessment started in Finland in the early 1970s. It was stimulated by the establishment of the Office of Technology Assessment, OTA in the USA, and by the growing interest within the OECD towards the methods of assessing the societal effects of technological change. SomeTA activities had emerged also in Sweden. Encouraged by these developments, the Science Policy Council of Finland ${ }^{1}$ proposed the Finnish National Fund for Research and Development (Sitra) to carry out a study on the theme. A young economist, with a background in costbenefit-analyses, Mr. Pertti Kohi, was invited to prepare thereport. At thetime, TAin Finland was understood primarily as cost-benefit-analysis of new technologies. The study was carried out under a auspices of a steering committee including high-ranking representatives from ministries, universities, and labour unions.

Sitra's report can be characterised as a guide to the methodology of TA. The TA framework developed by the Office of Science and Technology in the USA is introduced, but on the other hand it is stated that TA should be regarded more as a "movement" or a "tendency" than a method. The preconception that TA is 
quite similar to cost-benefit-analysis is also expressed in the report. Only one major difference between these two methods is mentioned: in addition to the cost-benefit-analysis, TA strives to recommend what practical measures should betaken. The pivotal purpose of TA is described as "making the assessment of the impacts of technology more precise" and serving as "a reminder to study the impacts of technology and to use the results in decision making". (Kohi, 1976: x, see also 22-23.)

The report also includes action proposals for the organisation of TA in Finland. Three of them are rather general, suggesting that 1) TA models of other countries should be systematically followed, 2) Finland should continue cooperation with the OECD in areas close to TA, and 3) the research planned and done on the effects of new technologies should be intensified and focused on "nationally important problems". These problems are not specified, but work conditions and forestry were mentioned elsewhere in the report. According to the report, TA issues should be integrated into technical education and into the continuing education of civil servants working for the municipalities or for the state.

Two of the proposals focus on the organisation of TA in Finland. It is suggested that the responsibility for testing and developing the TA would be given for instance to a unit in the Government Office or an ad hoc unit in the Ministry of Tradeand Industry. Moreover, it is recommended that a working group be set up with the task of establishing TA in Finland. The group should include representatives of the Government Office, Ministry of Trade and Industry, Ministry of Finance, Sitra, trade unions and industry (Kohi, 1976). There was no mention of involving the Parliament in the TA activities, however. TA was clearly considered as a tool for civil servants.

These action proposals were not carried out. According to Kohi (interview 5.11.1997), the specialists regarded after publishing the report that TA would not bring anything significantly new compared to the already used methods of cost-benefit analysis. Particularly in Scandinavia the methodology of costbenefit-analysis was expanding at the time and into the direction of growing attention to social and environmental costs and benefits. According to Kohi, TA was an extension of the existing evaluation methods rather than a new area of activity.

\section{Technology Assessment in the Shade of the Future Studies}

Future studies play a significant role in Finnish political and research culture. The interest in the future studies emerged in the 1970s growing up to an issue of political debate in the 1980s. TA has been of a minor importance in this discussion.

In the beginning of 1970's, some researchers became interested in the future studies, inspired mainly by the Club of Rome and its report on the limits of growth. At the end of the decade, two working groups were established with the aim at promoting future studies and the future studies education in Finland. First, there was a working group with representatives from the three Turku area universities with the aim at establishing a common future studies unit under their governance. 
Second, the Academy of Finland published in 1979 a report on the promotion of future studies in Finland (Academy of Finland, 1979). The work was presided by General Director of Technical Research Centre of Finland, Pekka Jauho. According to the report, the main reason for promoting future studies in Finland was the rapid development of technology and its consequences. The report encouraged the future studies to be decentralised between different research units under the co-ordination of the Academy of Finland. Moreover, establishing a special society for furthering the future studies was recommended. TA was considered as one field among the future studies, and again, particularly the importance of assessing the impacts of technological change on working conditions was mentioned. No references were made to parliamentary TA, although future studies at large were considered useful for the decision-makers. (Ibid. 2, 8, 28-31.)

The working group in Turku took it upon itself to establish the Finnish Society for Futures Studies in 1980. Seven Finnish multidisciplinary universities, four business schools and three technical universities were the founding members. The Academy of Finland accepted this society to function as the one mentioned in the Academy Report. ${ }^{2}$

In 1986, 133 citizens made a civil initiative suggesting that a unit for future studies would be established under the parliamentary jurisdiction. Inspired partly by this initiative, 136 Parliamentarians presented in 1986 a question to the government about "the threats and possibilities of the future" in Finland. The formulation of the text implies that the nuclear accident of Chernobyl in
1986 loomed behind the question. In their question, the Parliamentarians suggested that a unit for future studies should, indeed, be established. This idea was not greeted with enthusiasm by the Prime Minister Kalevi Sorsa. However, encouraged by the question, the Government asked for a statement from the Science Policy Council of Finland on organising future studies in Finland. After the parliamentary debate, also the Association of the Researchers and Members of Parliament arranged a discussion on future studies under the title "Is the future in the hands of the Parliament?" (Gabrielson, 1987). The representatives of the major political parties participated in the seminar agreeing on the need for studying the future of the Finnish society.

The Science Policy Council delegated the task to Ministry of Education, which established a committee to study the issue. The head of this committee was Academician Erik Allardt. In 1989, the committee published a report "Change, Choices, Future - the Promoting of Future Studies in Finland" (Commitee for Future Studies, 1989). Parliamentary technology assessment was discussed widely in the report. Both "traditional" and "constructivist" views were presented. In the conclusions, it was recommended that the Technical Research Centre of Finland be developed into a centre of TA in Finland. The parliamentary connections of the TA activity were not taken into account in the recommendations. (Commitee for Future Studies, 1989: 17-25, 62-63.)

After the committee's report, the Ministry of Education convened a working group to evaluate the recommendations. The group gathered 35 statements on the 
report, mainly from the ministries and universities. In its memorandum, the working group proposed establishing a Centre for Future Studies in Finland. In 1992, Finland Futures Research Centre was established. As far as TA is concerned, the working group emphasised, like the committee before, the importance of developing TA skills in the Technical Research Centre of Finland. Again, no parliamentary connections were mentioned, neither the assessing of the social impacts. The memorandum had very little significance on the development of TA activities.

\section{Discussions about Technology Assessment in the Society of Scientists and the Members of Parliament}

The promoter of technology assessment in the 1980 s and 1990 s was the Association of the Researchers and Members of Parliament (Tutkas). The Association was founded in 1970 following the model of the corresponding organisation in Sweden, RIFO (Förening för Riksdagsmän och Foskare). It was founded to increase communication between researchers and Members of Parliament in order to transmit scientific and technical expertise to the Parliament. Professor Jorma K. Miettinen, subsequently an academician, was a motive force behind the establishment of Tutkas. He gave very similar reasons for establishing Tutkas than the ones given in the early US debate concerning the need of TA: the rapid technological development has led to e.g. overuse of natural resources and pollution, and these problems require both applied research and corrective actions taken on the basis of the research. This would require better co-operation between researchers, legislators and engineers. (Miettinen, 1973.)

The first science policy programs were prepared by the scientific committees of the Academy of Finland in the 1960s, on the initiative of Ministry of Education. The Association's aim was also to increase the Parliament's capacity to contribute to the emerging science policy and help it deal with the problems related to the rapid development of science and technology. The members of the board of the Association were elected according to the relative strength of the political parties in the Parliament. The Association was also seen as an alternative to the Science Political Association, Tiepo, an organisation founded at the end of the 1960s by researchers with a leftist orientation. (M iettinen, 1973: 359.)

The Finnish PTA work that started after the mid 90s has its roots in Tutkas. One of the members active in the TA issue, Professor of Control Engineering, Antti J. Niemi (interview 9.6.1999) was a member of Tutkas' board for over two decades. His involvement with PTA dates back to the early 70 s, when he met Dr. Hugo Schuck, who was chosen to be the first Director of the Office of Technology Assessment (OTA) of the US Congress.

On the European level, the initiatives to start TA activities were stimulated and coordinated by theFAST-program (Forecast and Assessment in Science and Technology) funded by the Committee of the European Union. The program organised three conferences (in 1988, 1990 and 1992) in which researchers, parliamentarians, representatives of companies and trade unions from the 
European countries discussed the nature, methods and organisation of technology forecast and the TA activities. The representatives of Tutkas participated in these conferences.

A key person in the initiatives related to technology assessment in the 1990s was Member of Parliament Prof. Martti Tiuri, representative of the right-wing National Coalition Party and former Professor of Radio Engineering. He was the Chairman of Board of Tutkas and became also the Chairman of the Committee of the Future of the Finnish Parliament when it was established in 1993. Tiuri published already in 1984 a book "The future begins now" in which hereflected on the future of the Finnish information society. The importance of the advancement of high technology is the essential message of the book. In the view of Tiuri (1984: 224):

The Members of Parliament, burdened by many hurries tend not to have time to follow the development of society and their knowledgeeasily stagnates to the stage in which the MP started her/ his career. Particularly difficult is to follow the rapidly developing science and technology, although it is needed to understand information society.

Tiuri suggested that university professors of different fields, representing knowledge that influences the future, should bewidely invited asspecialiststo comment on the future in the committee hearings (Tiuri, 1984: 227).

In 1995, after appropriate discussions by Tutkas Board, Tiuri made, in his capacity as a Member of Parliament, a budget initiative for the Parliament suggesting funding, in the budget of 1995, for establishment of a project group on organising TA in Finland. The initiative became accepted, and a project group was established in 1995.

\section{The Parliamentary Committee for the Future}

In 1993, a special parliamentary committee was established in the Finnish Parliament: the Committee for the Future. Unlike the other Finnish parliamentary committees, this oneis not permanent, although it has been working uninterruptedly since its establishment. The establishing of the Committee for the Future was based on an initiative signed by 168 Parliamentarians, requiring the establishment of a permanent "Committee for Future Policy". The first signatory was Eero Paloheimo, Doctor of Technology and a representative of the Green Party. The initiative was rejected by the Committee for Constitutional Law. However, the Government was required to make an official account for the Parliament on the future development of Finland. In order to produce a parliamentary report on the Government's account, a temporary Committee for the Future was appointed in the Parliament in autumn 1993.

The first report of the Committee for the Future, commenting on theGovernment's account, came out in 1994 (Finnish Parliament, 1994). Technology was discussed only desultorily in the report, but the report drew attention to the problems of the decision-makershavein dealing with the technological knowledge. In the short final chapter, the committee concludes that significant legislativeand other ventures "with extensive economic, social or technological effects" should be made subject to an assessment procedure. 
The report also includes an objection byTiuri, wherehe underlines the significance of technology assessment:

Parliamentary committees can assess the social impact of ordinary bills, but issues in which scienceand technology are heavily involved are too complex and alien to be discussed in ordinary committee. [- - The aim of technology assessment (TA) is to give decisionmakers preemptive and impartial information about the possible positive, negative and indirect impact on society of technologies or ventures being developed. Another aim is to outline a scienceand technology strategy. (Tiuri, 1984: 56-57.)

Tiuri proposed setting up a TA office under the auspices of the Parliament. The office would act as a committee secretariat under the management of the Special Committee for the Future. The second report of the Special Committee for the Future came out in 1997. The weakening credibility of policy-making was mentioned, and thenegative effects of globalisation and the unmanageability of technological changewere discussed. (Finnish Parliament, 1997: 8-13, 17-22.) Thereport also touched on technology assessment:

In the future, innovations based on science and technology will change societyeven more. Increasingly often, there is a need for new legislation, in which science and technology feature significantly. Parliamentarians often haveinadequate information to assess theadvantages and drawbacks of new applications. There is a danger of the Parliament gradually losing a considerable part of its power of decision to government officials and experts. To be able to manage decision making better, the Parliaments have introduced assessment of the social impacts of technology. ... Technology assessment is an important means of understanding and managing the future development of the society. (Finnish Parliament, 1997: 52)

In the 1997 report, the Committee for the Future called for citizens' influence to strengthen the civil society and to complement parliamentary democracy through direct participation by citizens, or "small democracy" (Finnish Parliament, 1997: 20-21). However, the main concern werethechanged conditions of parliamentary decision-making. The committee considers that the societal importance of theissues outside thetraditional sphere of political decisionmaking had significantly grown. Technology assessment was considered as oneof thetoolsto make politicianscompetent in the new areas.

\section{The Organisation of TA in the Finnish Parliament}

On the initiative of 13 Members of Parliament, the Finnish Parliament reserved, in 1995, budget money for preparing a proposal for initiating technology assessment within the Finnish Parliament. Again, Tiuri was the first to sign the initiative. $60000 \mathrm{FIM}$ (ca. 10000 Euros) weregranted for the purpose, and a task group was appointed to prepare the proposal for organising TA, in September 1995. The Group for Technology Studies of the Technical Research Center of Finland was commissioned to do the preparatory work and to write the proposal, which was then submitted to the Parliament in December 1995.

The proposal covers the arguments for the need of TA in the Parliament. Along the need of understanding the complex issues of science and technol- 
ogy, more specific reasons were also presented. First, it was considered that the Parliament was poorly prepared for the discussions on the ever increasing amount of accounts on important and large-scale social issues brought to the Parliament by the government. With the TAstudies, the Parliament could prepare itself better for the debate and control better the activity of the government. Second, it was also considered important to deal more proactively with the complexissues involved in the directives of the European Union. Third, it was argued that TA serves also as a tool for the new basic function of the Committeefor the Future, the forming and evaluation of the alternative scenarios for the future.

As part of the preparation work, the task group visited the Bundestag of the Republic of Germany and its Office for Technology Assessment (TAB). To cite the expression of the director of theTAB, Professor Herbert Paschen, “TAB work is strictly oriented towards theinformation needs of the Bundestag" (Paschen, 1997: 10). The group was not interested in visiting the technology assessment institutions of Denmark (The Danish Board of Technology) nor Holland (Rathenau-Institute), which were more oriented to extended public debate on technology. Theorganisation ofTA in theBundestag, therefore, supplied the model and reference for the task group.

The task group recommended that the Committee for the Future takes the responsibility for technology assessment within the Parliament. It suggested, following the German model, that an outsideresearch centre becommissioned to prepare and carry out the assessment studies. According to the suggestion, this research should also follow the technology assessment activities in Europe and advance the technology assessment activities in Finland.

The technology assessment activity was started under the Committeefor the Future in 1996. A subcommittee of technology assessment was denominated in December 1996, and an annual budget of 350000 FIM (ca. 60000 Euros) was allocated for TA studies by the Parliament. No unit was established within the Parliament, nor were any specialised staff recruited for the purpose. Neither was any decision made to commission the preparation work of TA studies, or carrying it out to any outside research unit. The Sub Committee on TA chose, after hearing other Committees, the study subjects for assessment. The TA studies were done under the surveillance of a steering group appointed to each project by the Committee for the Future. The studies were carried out by independent research or consultancy organisations. The steering group includes a member from each interested parliamentary Committee. The Sub Committeeon TA was provided with one secretary.

\section{The Assessment Takes Shape: The First Three Projects}

By the autumn 1999, two technologyassessments and a prestudy had been accomplished. These assessments showed some differences in the approach and organisation of theresearch. At the same timethey revealed, however, a common conception of TA as supplying expert knowledge for the decision-makers. In thefollowing, theassessmentsarebriefly characterised. 
Study on Plant Biotechnology

At the end of 1997, the Committee for Future charged The Group for Technology Studies within the Technical Research Center of Finland, VTT, with the task of performing an assessment for the Parliament on the effects of plant gene technology on society. The assessment report was published in September 1998 (Salo et al., 1998). In November, it was discussed at the meeting of Tutkas and thereafter, in the plenary session of the Parliament. TheTA study was funded by the Parliament, and its purpose was defined by the chairman of the Sub Committee on TA, Tiuri, as "to act as a source of information and pavetheway towards debate in the Parliament" (Tiuri, 1998).

The assessment was carried out by a three-man working team consisting of a Doctor in Systems Analysis, an Emeritus Research Professor of Plant Biotechnology, and a Master of Art in Philosophy. The work relied mainly on two sources of information: firstly, on expert interviews among Finnish scientists and stakeholders, and secondly, on "secondary sources" like the OECD, FAO and ISAAA reports and foreign technology assessment reports. For the public opinion questions, recent opinion polls were introduced (Salo, 1998: 8-9).

Thefinal report consisted of some 200 pages and served quite well its intended function as an information package for decision makers. As such, the general approach of the study followed basically the model of rational decision-making. In many comments in theTutkas discussion and in the plenary session of the Parliament, the report was acknowledged as a many-sided and fully covering presentation of a complex subject.
However, in some comments, thereport was also criticised for lacking recommendations, for its expert-orientation, and for themarginal role of the consumers' point of view. The media attention was scanty, despite the press conference organised by the Committeefor Futures on the publication day.

Study on the Information and Communication Technology in the Finnish Educational System

Between 1997-1998, The Finnish National Fund for Research and Development (Sitra) on its part, was charged to carry out a TA study for the Committee for Futures on information and communication technology in theFinnish educational system. The assessment was completed in August 1998 and discussed at the meeting of Tutkas in October. The study was funded by Sitra, with a total budged of 2,3 million FIM (ca. 387000 Euros).

Theassessment was doneas an extensive expert evaluation, in which nearly one hundred specialists were involved. Besides the Parliamentary steering group, the project was managed by a project manager, (theformer head of the Information Technology Centre for Schools at the University of Helsinki) and by a management group consisting of sixteen authoritative representatives from the fields of education and information technology. The role of the new means of information and communication technologies was also accentuated in the project steering and in expert-network building (Sinko et al., 1998a: 1314).

The panels of experts conducted the assessment in threemain areas: A litera- 
ture review on the impacts of information and communication technologies on education, surveys on key players at all levels of the educational scene (e.g. administrators, teachers, students); and case studies of development projects of using information technologies in education (Sinko et al., 1998b: 5).

The assessment project produced eight published reports in over 1000 pages. As a large collection of information, the project reflects one of its originally intended functions of gaining experience of the methods of collecting knowledge. The collected information, however, remains quite dispersed and the storyline is hard to follow among the rambling data. The story in itself is not so complex. In the report, there is a consensual vision of the importance of bringing more information technology into the school system and education. Finland is said to be "an advanced laboratory of the information society"; however, stricter adherence to the national information technology strategy is required. As one of the main recommendations, a coherent national, communal, and institutional strategy is demanded for the full return of the investments in information technology (Sinko et al., 1998b).

Although massive in scope, the study of Sitra was only a part of a larger process. It was a separate thematic account in therenewal process of the national information society strategy that Sitra was charged to carry out in 1997-1998. In the working program of thestrategy process, the TA study for the Parliament was described as one separate account on the role of information and communication technologies. This directcommitment to national strategic planning and the ele- ments of visionary decision-making are features that distinguish theassessment from the more "rationalistic" study on gene technology. In visionary form, the other main objective of the study, the production of policy alignments, may also be said to have been fulfilled.

\section{Prestudy on Gerontechnology}

At the end of 1998, Sosiaalikehitys Ltd, a small research and development company in the health care sector, was chosen to carry out a TA prestudy on gerontechnology. The prestudy was completed after a good month of work in February 1999. The objectives of the prestudy were defined as: 1) To form a preliminary general view of gerontechnology in Finland, and of the Finnish connections with the foreign research and development in thefield; and 2) To raise special questions on the application of technology with aging people. The prestudy was based both on literature review and on expert interviews. In the report, some general trends and problems in the role of the elderly in the future society are presented. The main emphasis is on Finnish research and product development projects in the field of "gerontechnology".

In the basis of the first projects, the Committee for the Future has discussed thefuturetechnology assessment activities. The crucial question is the possible permanent organisation and status of the parliamentary technology assessment (cf. Sinko et al., 1998a, 10). It has been stated that the current practice of commissioning everyTA project to a different organisation may fulfil the Committee's idea of finding the bestTA practices and models in the national context 
(Sinko et al., 1998, 12). But, that this dispersion can also endanger the development ofTA knowledgeand expertiseand underminethe quality of futureTA studies (cf. Salo, 1998, 19).

The New Consensus on Technology Policy

In the 1990s, the consensus seeking national policy has adopted science and technology policy as one of its major themes. The common mission is the creation of an "innovative learning society" in which all the population is meant to contribute to the implementation and creation of thenew technologies and, through it, to the economic competitiveness. TheScienceand Technology Policy Council makes a triannual review of the science and technology policy. The aim of the innovative learning society was articulated, for the first time, in the review of 1990 (Science and Technology Council,1990). The two last reviews "Towards an innovativesociety" (1993) and "Finland - a knowledgebased society" (1996) figure the policy of creating a Finnish information society (1996,9):

Finland has set it as an objective to become one of the leading information societies not only in Europe but in the whole world. An information society is one in which the information and media industries are an important business sector, in which everyone has access to information services and skills to use them, and in which the procedures and structures of business life and the public sector have been developed with thehel p of information technology.

The different sectors of society are planned to contributeto this task. There is a fairly strong consensus in Finland about this policy, none of the political parties having questioned it. The telecommunicationsfirms, educational institutions and researchers are in a crucial position in therealisation of this program. The institutionalisation of technology assessment in Finland can easily beseen as part of this policy. Theassessment helps the Parliament take those measures contributing to the fulfilment of the national mission.

TheResearch and Development funding has increased rapidly in Finland focusing more on the technical sciences here than in other Nordic countries. The orientation to high technology and industrial innovation can be also seen in the organisation of the $R \& D$ funding. Finland istheonly Nordic country where the Ministry of Tradeand Industry is the foremost deliverer of $R \& D$ funding. The share of the National Technology Agency (a unit operating under the Ministry of Trade and Industry) of the public R\&D funding has grown from the $18 \%$ in 1990 to $30 \%$ in 1998 . In Finland, only $26 \%$ of the research funding goes directly to the universities, whereas the figure was 39\% in Sweden and Norway and 36\% in Denmark in 1995. A new feature in Finland is, that the projects including collaboration with firms are favoured in academic funding.

So far, only few critical comments on this national program have been presented by theacademicintellectuals (see Allardt 1997, 1998; Häyrinen-Alestalo, 1999). The critique in the journals Tiedepolitiikka (Science Policy), Tiedeja edistys (Science and Progress) and Science Studies as well as in the books on the university problems (Wiberg, 1995; Helenius et al., 1996), has mostly been 
in defence of the position and norms of academic basic research against the demands of immediate usefulness or economic utility. The strategy of favouring "units of excellence" in funding by the Academy of Finland has been questioned, as well as the implementation of management-by-results systems to universities and the use of the quantitative indicators, such as number of degrees as a criterion of funding.

\section{Conclusions}

Thehistory of theFinnish parliamentary technology assessment has three interrelated features. First, it follows the traditional conception of technology assessment, underlining the significance of specialist knowledge in facilitating the political decision-making within the Parliament. The Finnish solution follows, to a large extent, the German one, the production of research-driven assessmentreports for the Parliament. The orientation is clearly towards a specialist-driven assessment, in which the researchers collect and condenseessential knowledge for the Parliament to aid and support their decision making.

The acceptance of the traditional model is related to the second feature: Thesocial basisand supportfor technology assessment has remained limited. There is practically no TA research organised in theFinnish universities or research centres. Trade unions or thenongovernmental organisations have not been interested in TA. The whole matter has remained within the confines of the Finnish Parliament and technology administration. The key proponents of TA in Tutkas had their background in engineeringand technology, and wereactive in the Finnish Academy of Technology. The Academy is an engineering organisation, the purpose of which is to "promote technological sciences and their status in Finland and, in this way, to contribute to the success of Finnish industries ..." (Finnish Academy of Technology, 1999.) This professional background of the key proponents of the TA in Finland makes it understandable why the parliamentary technology assessment in Finland adopted a traditional, instrumental form.

Technology assessment has never been important political issue in Finland. Theseissues were integrated to the Parliament as a minor function or aspecial tool of theCommitteefor the Future, the organisation of which was a major political issue. Therefore, the distinct character and nature of technology assessment has remained rather undetermined and vague within the Parliament and even within the Committee for the Future. Only a small number of the Members of Parliament have been interested in developing TA.

Although TA and the Future Studies share a common concern for understanding and controlling the threads, influences and possibilities of technology, there are also differences. Whereas traditional TA underlines the necessity of careful multidisciplinary study on various, especially unwanted effects of technologies, the future studies focus on producing more general, long term alternative visions for the future society. In Finland, it was this latter idea that received political support and became institutionalised. Thus, TA was left in the shadow of the future studies in Finland in the 1980s and 1990s.

Thethird featurein the institutionali- 
sation of TA in Finland is its integration as a tool for the national program of creating an information society. This was evident particularly in the assessment project concerning the information and communication technologies. TheFinnish National Fund for Research and Development (Sitra) took responsibility of both the funding and the management of the project. This was logical, since Sitra is the main architect of the Finnish information society strategy. The assessment project focused on the key condition of this vision: the implementation of information technologies in the school system and in adult education.

The present way of organising parliamentary technology assessment in Finland involves a risk. No permanent staff has been hired to organise, study and develop the knowledge related to the execution and methods of assessments. Assessments done thus far have been contracted out to different actors on an ad hoc basis, with a limited budget and a short span for the assessment project. Combined with the limited social basis of the activity, thereisa risk involved that the knowledge and experience necessary for the development of technology assessment, as an open-minded, independent and systematic activity will not evolve at all in Finland. The Finnish TA risks remaining a small scale and amateur enterprise. Larger social implications of technology and the question of democracy - issues that have inspired the development of European technology assessment - have by and large been omitted.

\section{Notes}

1 The council, chaired by the prime minister, is the most important science policy organ in the Finnish political system. In 1987, it changed its nameinto the Science and Technology Policy Council of Finland.

2 Already in 1972, oneFinnish society for future studies was established: the Finnish Society for Technological Forecasting. It wasnot active for very long. Themembers were mainly from the field of technology. (Frey \& Mannermaa, 1990, 10.) Prof. Pentti Malaska, who was active in the Finnish Society for Futures Studies, finds a difference in the two societies' approaches towards future studies (interview 25.10. 1999). Finnish Society for Technological Forecasting was interested in such a pragmatic approach to future studies that has its background in military strategy making, for example the Delfoi and scenario methods; whereas the Finnish Society for Futures Studies can be viewed more as a society with a humanistic, "Flechtheimian" approach to future studies.

3 Interviews:

Pentti Kohi 5.11.1997

Antti Niemi 9.6.1999

Pentti Malaska 25.10.1999. 


\section{References}

Academy of Finland

1979 Tulevaisuudentutkimuksen edistäminen (The Advancement of Future Studies.) Suomen akatemia. Helsinki.

Agersnap, T.

1992 Consensus conference for technological assessment. Paper presented in the $3^{\text {rd }}$ European Congress on Technology Assessment in Copenhagen, 4-7 November 1992.

Allardt, E.

1987 Tiede ja yhteiskunta. (Science and society). In Väisänen A. (ed.) Tieteestä tiedottaminen. Helsinki.

1997 Tieteellisen työn muutokset janykyisen tiedepolitiikan vaarat (The changes of scientific work and the dangers of presentscience policy). Tiedepolitiikka 4/ 1997.

1998 Teknologiaretoriikka suomalaisen todellisuuden konstruoinnin välineenä. (Technology rhetorics as a means of construction the Finnish reAyano, $\mathrm{H}$. ality). Tiede \& Edistys 23, 86-95.

1999 Concensus conferenceon genetherapy in Japan, and understanding of advanced technologies. Paper presented at the Annual Conference of the Society fort the Social Studies of Science, San Diego, California, October 27-30, 1999

Bruun, K., Eskola, K. and Viikari, M.

1975 Tiedepolitiikka ja tutkijan vastuu. (Science policy and the responsability of the researcher). Helsinki: Tammi.

Cetron M. and Bartocha, B. (eds.)

1973 Technology Assessment in a Dynamic Environment. Gordon and Breach Science Publishers. London.

Commitee for Future Studies

1989 Muutos, valinnat, tulevaisuus - tulevaisuudentutkimuksen edistäminen Suomessa. (Change, choices, future the advancement of future studies in Finland) Tulevaisuudentutkimuksen toimikunta. Komietamietintö 1989:3. Helsinki.
Cronberg, T.

1992 Technology assessment in the Danish socio-political context. Unit of Technology Assessment. Technical University of Denmark. Technology Assessment texts 9 . Lungby.

Finnish Academy of Technology

1999 Http:// www.facte.com/

Finnish Parliament

1994 Report of the Special Parliamentary Committee for the Future on Finland's future options. Original Eduskunnan tulevaisuusvaliokunnan mietintö valtioneuvoston tulevaisuusselonteosta

1997 Report of the Special Parliamentary Committee for the Future. Original Eduskunnan tulevaisuusvaliokunnan mietintö valtioneuvoston tulevaisuusselonteosta. Osa 1 "Suomi ja Euroopan tulevaisuus"

Frey, $\mathrm{H}$. and Mannermaa, $\mathrm{M}$.

1990 Tulevaisuuden tutkimuksen seuran perustaminen (The establishment of the Society for Futures). Futura 9(2), $10-22$.

Gabrielsson, U. and Kangas, E. (eds.)

1987 Onko tulevaisuus eduskunnan käsissä? (Is the future in the hands of the parliament?) Tutkas julkaisuja 1.

Gabrielsson, U. (ed.)

1997 Mihin tiedepolitiikkaa tarvitaan?(Why science policy is needed?) Suomalainen tiede 2017. Tutkas julkaisuja 6.

Hetman, F.

1973 Society and theAssessment of Technology. OECD. Paris.

Helenius, B., Hämäläinen, E. and Tuunainen, J.

1996 Kohti McDonald'syliopistoa. (Towards a McDonald's University). Helsinki: Tammi.

Häyrinen-Alestalo, $M$.

1999 The University under the Pressure of Innovation Policy - Reflecting Some European and Finnish Experiences. Science Studies 12 (1), 44-69.

Immonen, $\mathrm{K}$.

1995 Suomen Akatemia suomalaisessa tiedepolitiikassa 1970-luvulla. (TheAcademy of Finland in the Finnish Science Policy in the 1970s). Helsinki: Otava. 
Kaakinen, J. and Törmä, S.

1999 Esiselvitys geronteknologiasta. Teknologian arviointeja 5. (Preliminary Study on Gerontechnology. Technology Assessment 5.) Tulevaisuusvaliokunnan teknologiajaosto. Eduskunnan kanslian julkaisuja 2/ 1999.

Kekkonen, J.

1998 Suomen oikeushistorian suuri linja. (The great line of the Finnish juridical culture) Suomen lakimiesyhdistyksen

Kohi, P. julkaisuja C-Sarja N:ro 32.

1976 Teknologian vaikutusten arviointi Technology Assesment. Suomen Itsenäisyyden Juhlavuoden Rahasto. Sarja B. Nro 21. Helsinki 1976.

Miettinen, J. K.

1973 Tutkijoiden ja kansanedustajien seura. (Theassociation of theresearchersand members of Parliament.) Kanava 6/ 1973, 359-361.

1978 Mitä ajateltiin, kun Tutkas perustetti in ja kuinka sitä voidaan kehittää? (What wasthought, when Tutkas was founded and how can it be developed?) Paper presented in the general assembly of Tutkas 22.3.11.1978.

Miettinen, $\mathrm{R}$.

1996 Julkista päätöksentekoa palveleva teknologian arviointitoiminta Euroopan maissa: ehdostus teknologian arviointitoiminnan järjestämiseksi eduskunnassa. (Technology assessment activity serving public decision making in Europe and the organizing assessment activity within the Finnish Parliament). VTT Teknologian tutkimuksen ryhmä. Työpapereita 27.

Miettinen, R. and Väliverronen, $\mathrm{E}$.

1999 In science we trust; on the public understanding of science in Finland. In Miettinen, R. (ed.) Proceedings of the UK-Nordic Co-oprerativeseminar, Helsinki, October 25-27, 1998, 11-22.

Paschen, $\mathrm{H}$.

1977 The Technology Assessment Bureau of the German Parliament. Paper presented at the Annual Meeting of the Society for Social Studies of Science. University of Arizona, Tucson 22-26, 1997.
Salo, A.

1998 Kokemuksia teknologian arvioinnista: Kasvigeenitekniikka ravinontuotannossa. (Experiences on Technology Assessment: Plant Gene Technology in Food Production) VTT teknologian tutkimuksen ryhmä. Työpapereita 37/ 98.

Salo, A. and Kauppinen, V.

1997 Esiselvitys kasvigeenitekniikasta. Teknologian arviointeja 1. (Preliminary Study on Plant GeneTechnology. Technology Assessment 1.) Tulevaisuusvaliokunnan teknologiajaosto. Eduskunnan kanslian julkaisuja 3/ 1997.

Salo, A., Kauppinen, V. and Rask, M.

1998 Loppuraportti kasvigeenitekniikasta Kasvigeenitekniikka ravinnontuotannossa. Teknologian arviointeja 3. (Plant Gene Technology in Food Production. Technology Assessment 3.) Tulevaisuusvaliokunnan teknologiajaosto. Eduskunnan kanslian julkaisu 4/ 1998.

Science and Technology Council of Finland

1990 Guidelines of science and technology policy in the 1990s. Helsinki.

1993 Towards an innovativesociety. A development strategy for Finland. Helsinki.

1996 Finland: A knowledge-based society. Helsinki.

Sinko, M. and Lehtinen, E. (eds.)

1998a Bitit ja pedagogiikka - tieto- ja viestintätekniikka opetuksessa ja oppimisessa. (Information and Communication Technology in Finnish Education, theFinal Report.) Jywäskylä: Atena kustannus. Sitran julkaisusarjan nro 194.

Sinko, M. and Lehtinen, $\mathrm{E}$.

1998b Tieto ja viestintätekniikka opetuksessa ja oppimisessa - tulokset ja toteutus. (Information and Communication Technology in Finnish Education - Results and Realisation. Technology Assessment 4.) Tulevaisuusvaliokunnan teknologiajaosto. Teknologian arviointeja 4. Eduskunnan kanslian julkaisusarja 5/ 1998. 
Tiihonen P.

1997 The Parliament-Government Discourse on Future Options. A Presentation in Speyer 14.-18.10.1997. (〈http:/ / www.eduskunta.fi/fakta/vk/ tuv/ luento.htm>)

Tiuri, M.

1984 Tulevaisuus alkaa nyt. (The future begins now). Helsinki: Otava.

1998 "To Parliament" - introduction in Salo et al. (1998). Report on Plant Gene Technology in Food Production. Finnish Parliament. The Technology section of the Committee of the Future. EdusVig, N. kunnan kanslian julkaisusarja 4/ 1998.

1997 Parliament and technology: The development of technology assessment in Europe. Paper presented at the Annual Meeting of the Society for Social Studies of Science.University of Arizona, Tucson 22-26, 1997.

Wiberg, M. (ed.)

1995 Yliopisto uusiksi! (Renew the university!) Helsinki: Gaudeamus.

Reijo Miettinen

Center for Activity Theory and

Developmental Work Research

University of Helsinki, Finland

\author{
Riikka Eela \\ Mikko Rask \\ Group for Technology Studies \\ VTT, Technical Research Centre of \\ Finland, Espoo, Finland
}

